\title{
Feathers of Little Egret (Egretta garzetta) Fledglings as a Bio Monitoring Tool for Mercury, Arsenic, Cadmiumand Lead Pollution in Sri Lanka
}

\author{
Ravindra Lakshantha Jayaratne, Inoka Chinthana Perera, Devaka Keerthi Weerakoon, \\ Sarath Wimalabandara Kotagama
}

University of Colombo, Colombo, Sri Lanka

Email address:

ravindrajayaratne@yahoo.com (R. L. Jayaratne), icperera@sci.cmb.ac.lk(I. C. Perera), devakaw@gmail.com (D. K. Weerakoon), Fogs11976@slt.1k(S.W. Kotagama)

\section{To cite this article:}

Ravindra Lakshantha Jayaratne, Inoka Chinthana Perera, Devaka Keerthi Weerakoon, Sarath Wimalabandara Kotagama. Feathers of Little Egret (Egretta garzetta) Fledglings as a Bio Monitoring Tool for Mercury, Arsenic, Cadmiumand Lead Pollution in Sri Lanka. International Journal of Ecotoxicology and Ecobiology. Vol. 4, No. 4, 2019, pp. 103-113. doi: 10.11648/j.ijee.20190404.14

Received: July 15, 2019; Accepted: October 22, 2019; Published: December 10, 2019

\begin{abstract}
The objective of this study is to establish a baseline set of data for heavy metal contaminants in diverse ecosystems in Sri Lanka using bird feathers as a bio monitoring tool. During May to July 2014 heavy metal concentration (Hg, $\mathrm{As}, \mathrm{Cd}$ and $\mathrm{Pb}$ ) was assessed in bird feathers and regurgitated materials of Little Egrets (Egretta garzetta) and water collected within the foraging areas at five heronries from three districts of Sri Lanka. A significant variation of $\mathrm{Hg}$ and As $(p<0.05)$ was observed. But such a significant variation was not observed for $\mathrm{Cd}(p>0.05)$. Only As concentration of regurgitated materials show significantly variation between sites $(p<0.05)$ whereas no significant variation in $\mathrm{Hg}$ and $\mathrm{Cd}(p>0.05)$. In all sites, for all four metals there were some significant variations of metal concentrations in water. $\mathrm{Pb}$ was only detected in water and no more in feathers and regurgitated materials. The concentration of $\mathrm{Hg}, \mathrm{As}, \mathrm{Cd}$ and $\mathrm{Pb}$ were generally within the normal background level and mostly below the threshold level that may affect bird survival and reproduction. According to the results of the present study, feathers of Little Egret fledglings can be used as a bio-monitoring tool to measure the bio accumulation of $\mathrm{Hg}$, As and $\mathrm{Cd}$ except $\mathrm{Pb}$ with combination of metal concentration of their regurgitated materials and water that was collected from the surroundings of heronries.
\end{abstract}

Keywords: Bioaccumulation, Heavy Metals, Little Egrets, Feathers

\section{Introduction}

Sri Lanka is an island identified as a hotspot of biodiversity both for fauna and flora. Since Sri Lanka is going through a phase of industrialization and rapid urbanization during the last four decades there is trend of increased release of pollutants in to air, water and land resulting in serious environmental problems [2].

Emissions from the automobiles are the main source of ambient air pollution in Sri Lanka. In Colombo city over $60 \%$ of total emissions come from automobiles [3]. The permissible ambient air quality standards were introduced for selected air pollutants under the National Environmental (Ambient Air Quality) Regulations of 1994 [4]. By adopting the National Policy on Urban Air Quality Management in year 2000, some measures have been introduced to reduce air pollution resulting from automobile emissions. These include a ban on the use of leaded gasoline in June 2002, introduction of diesel with low sulfur in January 2003, banning of the importation of two stroke three-wheelers in 2008, and implementation of a mandatory vehicular emission-testing program in year 2008 . However, due to lack of an efficient public transport system, people are forced to use private transport which has lead to a rapid increase in number of new vehicles released to the roads, and contributed to a rapid rise in the amount of effluents released from the automobiles to the environment [3]

Although Sri Lanka has a large network of water resources, drinking water sources of the island are being polluted due to various anthropogenic activities [2]. The major drivers of water pollution in Sri Lanka include 
agriculture, urbanization and industrialization that have contributed to drastic changes in land use patterns. According to Ileperuma [2], environmental contaminants have been increasing in past decades due to urbanization and industrialization, resulting in reduction of the quality of water bodies in Sri Lanka as a result of runoff containing these effluents.

Although there are many past studies in Sri Lanka using number of fauna and flora as biomonitors, there are no published documents on the feasibility of using birds as a biomonitors. By analyzing heavy metals in water within the foraging area of the heronries, it gives a clear idea about the heavy metal concentrations of the initial stage in food chain. Heavy metals in plankton can also be detected by measure levels in water. Thus total heavy metal concentration in a water sample will include heavy metals in water column and plankton it may express metal concentration in primary level of a food chain and also whether these metals are accumulated through the food chain or not. Ultimately, the aim of the current study is to find out the possibility of using bird feathers as a less expensive biomonitor to determine the spatial and temporal pollutant profiles of selected ecosystems in Sri Lanka.

Because of practical and ethical reasons, new methods for nondestructive biomonitoring are being developed instead of using free living animals as biomonitors [5]. Using feathers is a nondestructive method where feathers can be taken from live birds [6]. It is easier to sample feathers than other tissues even from remotely located populations, since feathers can be stored without special equipment or conditions [5].

Many species of birds can be used as biomonitors. In freshwater ecosystems of Sri Lanka, there are several species of birds that can be encountered readily. These include cormorants, egrets and herons. Out of these, egrets are more suitable as biomonitors as they tend to utilize a wide array of wetland microhabitats compared to cormorants and herons [7].

The diet of herons and egrets (family Ardeidae) mainly consist of fish [7]. As large fish eating birds, they assume the highest trophic level in aquatic ecosystems. Since they have the ability to accumulate pollutants and heavy metals that are non bio degradable [8], they can be used as biomonitors to assess the pollutant levels in aquatic systems [9-12]. Also, the changing levels of pollutants within lower tropic levels can also be mapped using these indicators [13, 14]. Humans exploit most aquatic fauna as a source of food [15]. Therefore, having continuous monitoring of pollutants levels flowing through the food webs in aquatic ecosystems is vital to ensure human wellbeing.

\section{Methodology}

\subsection{Species Selection}

Little Egret (Egretta garzetta) was selected as the indicator species in the current study, since they are widespread and found in all climatic zones of the Sri Lanka and susceptible to bioaccumulation of many heavy metals through food chains $[5,16,17]$.Field observations were carried out once a week in selected sites to find out the preferable foraging grounds during their breeding seasons. Further, preliminary observations were carried out to get a general knowledge on seasonal variations, peak nesting time and number of nests per site of each egret species in the field by using binocular (Nikon; $10 \times 40$ ). Foraging grounds of birds were identified by following them on motorbikes. Although other bird species were identified in these heronries except egrets, their numbers was not taken since it is not crucial for this study.

\subsection{Study Sites}

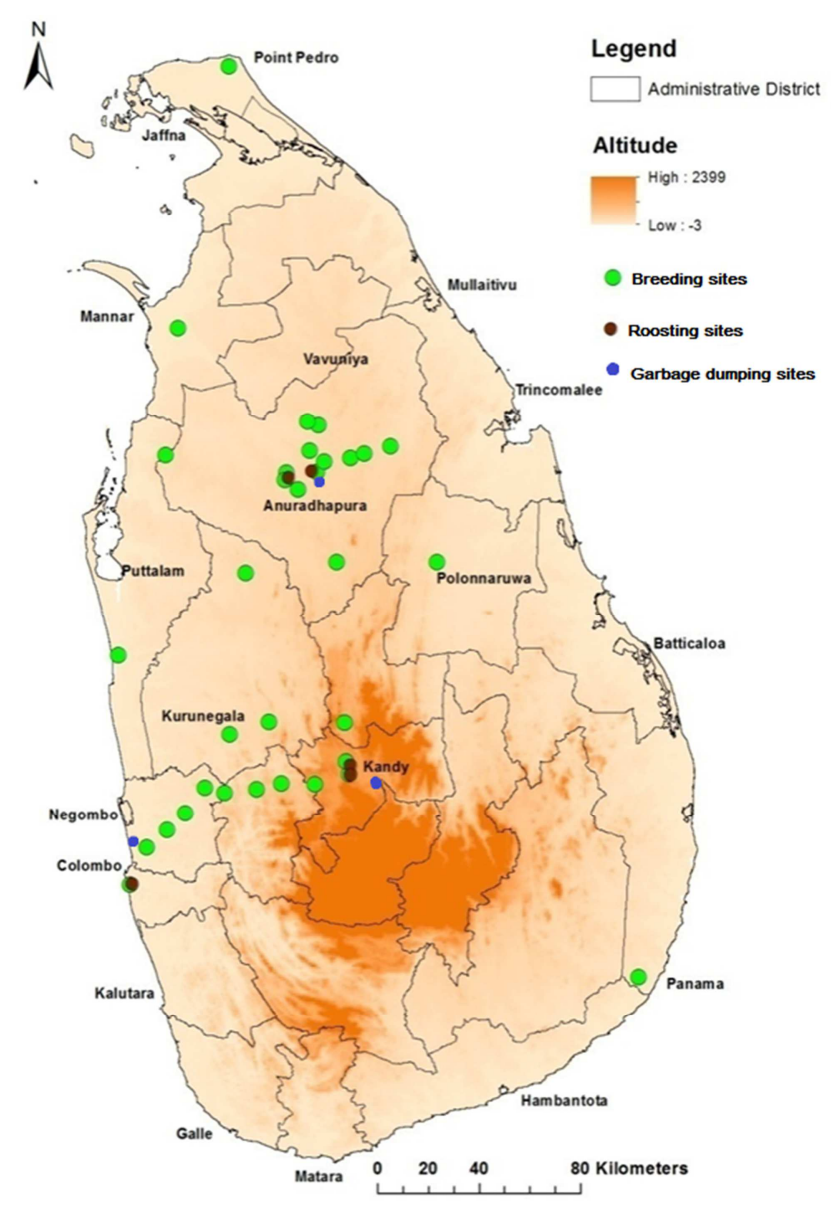

Figure 1. Map of the study sites.

Since Sri Lanka has diverse climatic zones, pollutant sources and their effects on fauna and flora can vary accordingly. Identifying these vulnerable areas is vital in management of ecosystems. Land use patterns and socioeconomic status of surrounding human settlements as well as the status of development can influence the amount of heavy metals released to the environment [2]. Hence, it was a complex task to select a typical study site for this pioneer study. Past studies carried out on feeding, breeding and behavior of birds $[16,18,19]$, detailed maps of Sri Lanka as well as past literature along with field observations were used in selecting study sites.

Based on these considerations, three areas were selected 
for this study, Colombo and Gampaha as industrial areas in the wet zone, Anuradhapura as an agricultural area in the dry zone and Kandy as a traditional farming area in the intermediate zone. Five heronries of little Egrets were identified from three areas, Gampaha, Kandy and Anuradhapura (Figure1), namely Belummahara $\left(7^{\circ} 66^{\prime} 06^{\prime \prime} \mathrm{N}\right.$, $\left.80^{\circ} 12^{\prime} 13^{\prime \prime} \mathrm{E}\right)$ in Gampaha district, CTB depot site $\left(8^{\circ} 32^{\prime} 35^{\prime \prime} \mathrm{N}, \quad 80^{\circ} 39^{\prime} 71^{\prime \prime} \mathrm{E}\right)$ and Jaffna Junction site $\left(8^{\circ} 35^{\prime} 55^{\prime \prime} \mathrm{N} / 80^{\circ} 41^{\prime} 68^{\prime \prime} \mathrm{E}\right)$ in Anuradhapura district, Kandy Lake site $\left(7^{\circ} 17^{\prime} 47^{\prime \prime} \mathrm{N}, 80^{\circ} 38^{\prime} 16^{\prime \prime} \mathrm{E}\right)$ and Kadugannawa $\left(7^{\circ} 26^{\prime} \mathrm{N}, 80^{\circ} 53^{\prime} \mathrm{E}\right)$ in Kandy district.

\subsection{Sample Collection and Preparation}

Other than fledglings feather samples of Little Egrets,water samples from foraging areas of adults in each heronry, regurgitated samples of Little Egrets, were collected from each heronry.

The Flight feathers were plucked freshly from Little Egret fledglings who are at 6-7 weeks old for sampling $(n=50)$.After measuring weights, the collected feathers of all species were stored in metal free polythene bags until preparation for analysis. Then they were washed in deionized water and alternated with acetone to remove contaminants such as dirt and fecal matter [20].

Fifteen water samples were collected from foraging areas of all sites in 2014 breeding season into metal free bottles which were treated with $10 \% \mathrm{HNO}_{3}$. These samples were initially acidified with nitric acid and were transported and stored at $4^{\circ} \mathrm{C}$ before analysis as soon as possible to minimize changes of the physicochemical characteristics of the metals [21].

Regurgitated samples were collected during the process of collecting feathers for metal analysis, since fledglings regurgitated their last meal when they are disturbed. All materials that were collected from a colony were pooled and sorted out in to the species level. Each specimen was washed with deionised water and analyzed species wise for heavy metals in each site.

\subsection{Heavy Metal Analysis}

Approximately $0.5 \mathrm{~g}$ from each feather and regurgitated samples were analyzed in the analytical chemistry laboratory, Institute of Post Harvest Technology (IPHT), NARA for As, $\mathrm{Hg}, \mathrm{Cd}$ and $\mathrm{Pb}$. By using the CEM/MARS XP-1500+ microwave oven the samples were digested with 800 psi working pressure and temperatures up to $200^{\circ} \mathrm{C}$. Thereafter, $10 \mathrm{ml}$ of Conc. $\mathrm{HNO}_{3}$ (AR-Sigma) was added for each sample. Analytical reagent blanks and spikes were used as controls. The digested samples were transferred to50 $\mathrm{ml}$ volumetric flasks, and volume was increased up to $50 \mathrm{ml}$ using de-ionized water. Samples were tested for $\mathrm{Cd}, \mathrm{Pb}$ and As using Palladium Nitrate as a binding agent for As by
Spectra AA 220 Zeeman Atomic Absorbent Spectrophotometer with graphite tube atomizer (Varian AA 240 FS) Further samples were tested for $\mathrm{Hg}$ using a Cold Vapor Atomic Absorbance Spectrophotometer (Varian VGA77). The data were analyzed by using $\mathrm{R}$ (3.2).

\section{Results and Discussion}

Adult feathers not only represent local exposure but also reflect metals accumulated through past intake. Removing excessive amounts of external pollutants that contaminate the egret feathers is complicated and hence could affect the final results. Therefore, use of fledgling feathers (6 to 7 weeks old) to explain spatial and temporal metal levels of a particular ecosystem is more meaningful compared to utilizing adult egrets.

Although theoretically all four metals should be accumulated through water to regurgitated materials and to feathers, no accumulation of $\mathrm{Pb}$ could be observed through water to feathers. Only the accumulation of $\mathrm{Hg}$, $\mathrm{As}$ and $\mathrm{Cd}$ was observed in this particular food chain except in certain heronries. However, this observation lacks evidence to claim that $\mathrm{Pb}$ is not present in the environment. According to the past studies, $\mathrm{Pb}$ is mostly deposited in avian bones followed by other tissues [22-25]. However, $\mathrm{Pb}$ was detected in feather samples of Cattle Egrets and Intermediate Egrets. Further, $\mathrm{Pb}$ was detected in water and regurgitated samples throughout the study in all sites. At certain times $\mathrm{Pb}$ concentration of water was observed to be significantly higher than that of $\mathrm{Hg}$ and $\mathrm{Cd}(p<0.05)$.

\section{1. $\mathrm{Hg}, \mathrm{As}, \mathrm{Cd}$ and Pb Concentration in Fledgling Feathers}

One-way ANOVA was applied to investigate the presence of variation between fledgling feather samples of Little Egrets collected from five sites for $\mathrm{Hg}, \mathrm{As}, \mathrm{Cd}$ and $\mathrm{Pb}$ concentrations $(\mathrm{Hg} ; \mathrm{F}=0.46, P<0.05$, As; $\mathrm{F}=8.75, P<0.05$, $\mathrm{Cd} ; \mathrm{F}=1.18, P=0.2821$ ). A significant variation of $\mathrm{Hg}$ and $\mathrm{As}$ $(p<0.05)$ concentrations in Little Egret fledgling feathers was observed and such significant variations were not observed for Cd ( $p>0.05)$ between sites. The Tukey's test was used to identify significant differences between mean values of five sites for the metals which were found to be significant in one-way ANOVA test. Tukey's test shown that, the mean $\mathrm{Hg}$ concentration of feathers was significantly high in Belummahara site in Gampaha district $(p<0.05)$. However, multiple comparison tests showed that As concentration was higher in feathers collected from Kadugannawa site than that of Kandy lake. Although there was no difference in $\mathrm{Cd}$ concentrations among all sites, multiple comparison tests showed that the Cd concentration in Kadugannawa site is comparatively high (Figure 2). 


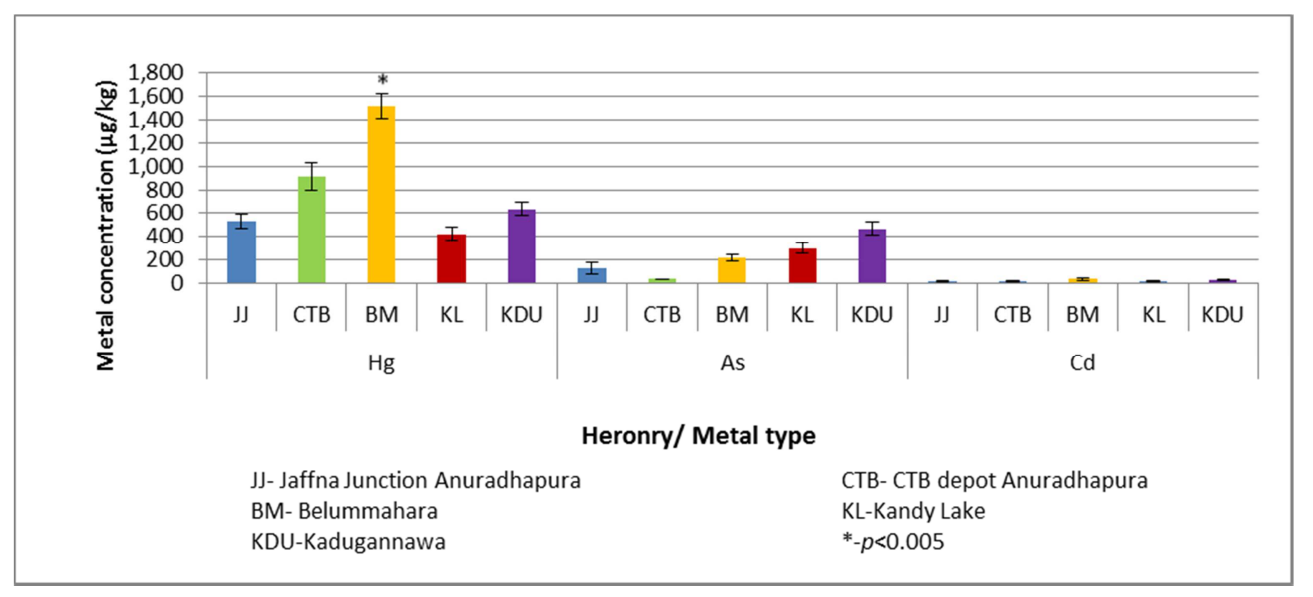

Figure 2. Mean heavy metal concentration in fledgling feathers of Egretta garzetta( $\mu \mathrm{g} / \mathrm{kg})$.

Human settlements, paddy fields, vehicle service stations, hotels and other commercial buildings were common within 3-4 $\mathrm{km}$ radius of the foraging area in Belummahara. The $\mathrm{Hg}$ concentration of feathers in Belummahara was exceed the mean $\mathrm{Hg}$ concentration of feathers in Little egret ( 0.21 to $0.97 \mathrm{ppm})$, Intermediate egret $(0.22 \mathrm{ppm})$ and Cattle egret $(0.10 \mathrm{ppm})$ of Pakistan, discovered by Boncompagni, Muhammad [26]. Also $\mathrm{Hg}$ concentration of feathers in present study was almost similar to the mean $\mathrm{Hg}$ concentration of Little egrets (1.69 ppm) observed by Goutner and Furness [27]. The Zhang, Ruan [28] found that higher mean $\mathrm{Hg}$ concentration of little egrets in Perl Delta of China (2.09 ppm) than present study. However the other two sites, Poyang $(0.41 \mathrm{ppm})$ and Tai $(0.64 \mathrm{ppm})$ were lower than present study. Frederick, Spalding [29] found that Hg in Great egret nestlings of eleven colonies in Florida, range lowest in St Martin (1.8 ppm) to highest in L-67 (13.7 ppm). The Tsipoura, Burger [30] reported that; mean $\mathrm{Hg}$ concentration of Canada geese in three sites of Meadowlands range from $0.2 \mathrm{ppm}$ to $0.3 \mathrm{ppm}$, where it was lower than present study. However Sepúlveda, Frederick [31] observed higher $\mathrm{Hg}$ concentration of Great egret feathers (16 ppm in 1994 and 9.7 ppm in 1995) in Southern Florida than present study of Sri Lanka. However the Padula, Burger [32] reported that the $\mathrm{Hg}$ concentration of Night heron chicks from New York harbor Estuary was range from 1.0 to 1.5 $\mathrm{ppm}$. That was much similar to the present study.

Previous studies have shown that the elevated $\mathrm{Hg}$ concentrations can impact bird behavior, physiology and reproductive success [33-36]. Moreover, Carty and Malone [37] showed that there is high efficiency in absorbing methyl mercury in the diet in the vertebrate digestive tract. $\mathrm{Hg}$ concentration of feathers above $5000 \mathrm{ppb}$ affects the reproduction of birds $[6,36,38,39]$ Although, there was no such detections in the present study, the continuous releasing of toxins into aquatic environments will increase the $\mathrm{Hg}$ concentrations in feathers in the near future.

The results show that mean Arsenic concentration of feathers was high in Kadugannawa site $(0.51 \mathrm{ppm})$ in Kandy district (Figure 2). Foraging areas of egrets included Nanuoya river and certain paddy fields occupied within 3-4 $\mathrm{km}$ radius from the centre of the heronry. Moreover, human settlements, vehicle service stations, hotels and paddy fields were common within the foraging areas of adults. Further, the Colombo-Kandy railway and main road are located parallel to the Nanuoya stream and this water body is contaminated with automobile effluents runoff with rain water. Staszewski, Malawska [40], has reported that As concentration exceeds the toxic levels in soils at both sides of railways. Solutions of As used for seasoning the railway ties as chromate copper arsenate (CCA) which can be easily leaked to the soil [41]. This may be the reason for high concentrations of As values detected in feathers collected from Kadugannawa area. The values show some similarity for findings of [26] of Little egret (0.1 to $0.48 \mathrm{ppm})$ and greater than Cattle egret $(0.10 \mathrm{ppm})$. According to the Zhang, Ruan [28], the mean As concentration of little egrets in Perl Delta of China $(0.11 \mathrm{ppm})$ lower than present study. The Tsipoura, Burger [30] reported that; mean As concentration of Canada geese in three sites of Meadowlands range from $0.006 \mathrm{ppm}$ to $0.19 \mathrm{ppm}$, lower than present study. The Nighat, Iqbal [42] reported that some mean As concentrations in feathers of Raptors in Pakistan, Steppe eagle (4.74 ppm), Black kite $(9.46 \mathrm{ppm})$ and Shikra $(28 \mathrm{ppm})$, that were greater than values of present study, however the values of present study was higher than As concentration of Night heron chicks from New York harbor Estuary (0.001 to $0.09 \mathrm{ppm}$ ), that reported by Padula, Burger [32]

Sites wise, no significant variation was observed of $\mathrm{Cd}$ concentration in feathers. However, according to the multiple comparisons, the mean $\mathrm{Cd}$ concentration of feathers was high in Kadugannawa site $(0.02 \mu \mathrm{g} / \mathrm{g})$ (Figure 2). It was lower than that reported in previous studies, Malik and Zeb [43], reported mean Cd concentration vary from 2.4 to $3.1 \mu \mathrm{g} / \mathrm{g}$ in the feathers of Cattle egrets in Pakistan and Fasola, Movalli [44], reported that the $\mathrm{Cd}$ in little egret $(0.6 \mu \mathrm{g} / \mathrm{g})$ and blackcrowned night heron $(0.6 \mu \mathrm{g} / \mathrm{g})$ in the northern Italy and Burger and Gochfeld [45] reported that $\mathrm{Cd}$ concentration $0.14,0.43,0.05$ and $0.07 \mu \mathrm{g} / \mathrm{g}$ for black-crowned night heron, cattle egret, little egret, and great egret from Hong Kong. The Padula, Burger [32] reported that the $\mathrm{Cd}$ concentration of Night heron chicks from New York harbor 
Estuary was range from 0.059 to $0.16 \mathrm{ppm}$. That was much higher than the present study.

The mean $\mathrm{Cd}$ concentration measured in Little egret feathers in the current study was not exceeding threshold concentration of $2 \mu \mathrm{g} / \mathrm{g}$, that may have adverse effect in kidneys [46].

In the current study $\mathrm{Pb}$ was not detected in feathers and in any sites, however according to previous studies $\mathrm{Pb}$ was reported in feathers of various birds' species: Franklin's gull [47], Pigeon guillemots [48], Great tits and Green finch [49], Terek sandpiper, Great knot, dunlin and Mongolian plover [50], Cattle egrets [43]. According to the Burger and Gochfeld [45]; Fasola, Movalli [44] and Movalli [51] that Pb concentrations in feathers are mainly due to the continued use of leaded gasoline. Also Metcheva, Yurukova [52]shows that Lead is readily accumulates in bones, hairs, feathers and nails.

\section{2. $\mathrm{Hg}, \mathrm{As}, \mathrm{Cd}$ and $\mathrm{Pb}$ in Regurgitated Materials}

One-way ANOVA was applied to investigate the presence of variation between regurgitated samples of Little Egrets collected from five sites for $\mathrm{Hg}, \mathrm{As}, \mathrm{Cd}$ and $\mathrm{Pb}$ concentrations in $2014(\mathrm{Hg} ; \mathrm{F}=1.63, P=0.2028$, As; $\mathrm{F}=0.43$, $P<0.05, \mathrm{Cd} ; \mathrm{F}=1.88, P=0.1453)$. A significant variation of As $(p<0.05)$ concentrations in regurgitated materials was observed and although species diversity was observed in regurgitated samples of Little Egrets such significant variations were not observed for $\mathrm{Hg}$ and $\mathrm{Cd} \quad(p>0.05)$ between sites. The Tukey's test was used to identify significant differences between mean values of five sites for the metal which was found to be significant in one-way ANOVA test. Tukey's test shown that As concentration was significantly high in regurgitated materials collected from Belummahara site $(p<0.05)$. However, it should be noted that only three regurgitated material samples collected from Belummahara and Kadugannawa heronries were utilized to detect the As concentration. All these samples belonged to phylum Arthropoda, two were grass hopper samples and one was a Crab sample.

Moreover, multiple comparison tests showed that $\mathrm{Hg}$ and $\mathrm{Cd}$ concentrations of regurgitated materials were high in Kandy lake than other sites (Figure 3).

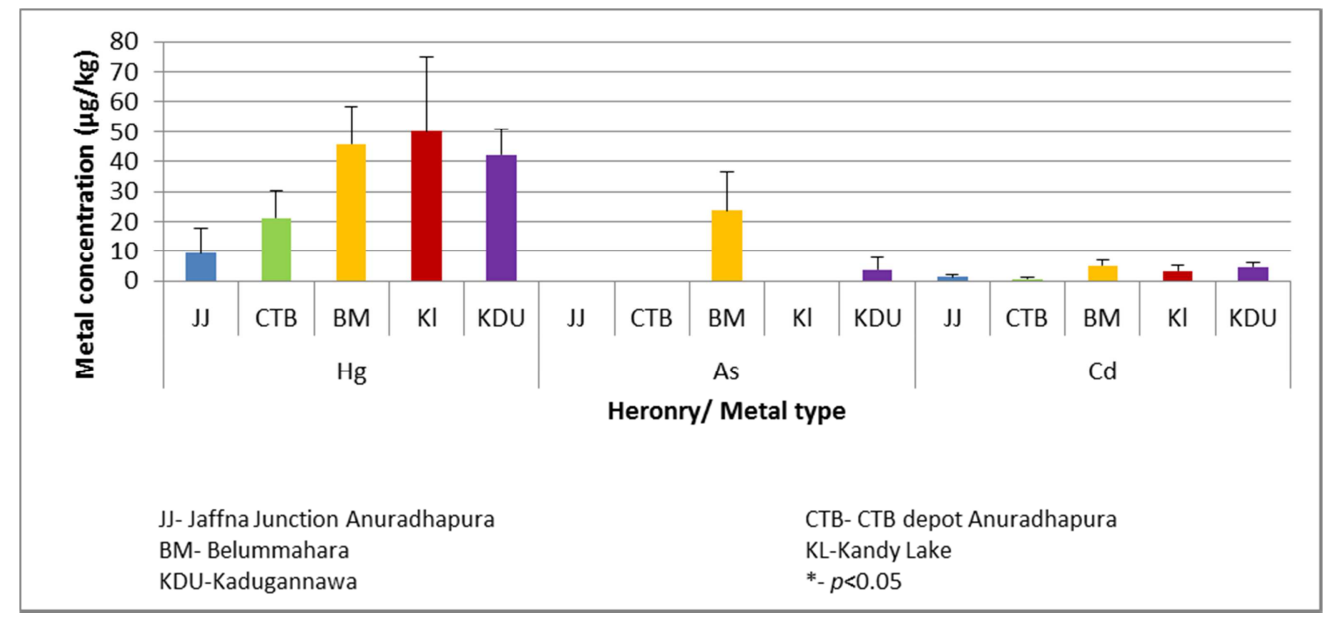

Figure 3. Mean metal concentration in regurgitated materials of Egretta garzetta( $\mu \mathrm{g} / \mathrm{kg})$.

The adults' birds of this heronry are foraging in paddy fields, streams and tank itself which have been contaminated with runoff water from roads with automobile effluents, waste water from hotels and residence within catchment area through municipal canals When consider the regurgitated samples that were collected from fledglings of Kandy lake, Amblypharyngodon melattinus, puntius dorsalis, Puntius filamentosus, Esomus thermoicos were common. The $\mathrm{Hg}$ concentrations of prey items in Intermediate egret $(0.1 \mathrm{ppm})$, Little egret $(0.57 \mathrm{ppm})$ and Cattle egret $(0.03 \mathrm{ppm})$ that detected by Boncompagni, Muhammad [26] in Pakistan show similarity to present study. The Zhang, Ruan [28] found that highermean $\mathrm{Hg}$ concentration in prey items of little egrets from Tai lake (0.24 ppm), however $\mathrm{Hg}$ concentration of prey items from Poyang Lake (0.1 ppm) much same as present study.

Also the values of present study much same as the lower $\mathrm{Hg}$ concentration of two fish species, Etroplus suratensis(0.10 - $0.51 \mathrm{ppm})$ and Ambassis commersoni (0.1-
$0.53 \mathrm{ppm}$ ) that detected by the Indrajith, Pathiratne [53] from 12 sites ofNegombo estuary. There are many studies of $\mathrm{Hg}$ concentration of freshwater fish fauna in Sri Lanka. Jinadasa, Ariyarathne [54] observed that $\mathrm{Hg}$ in inland fish species Orinoco Sailfin Catfish (Pterygoplichthy smultiradiatus) (Male: - 0.043 and Female: - $0.044 \mathrm{ppm}$ ) from two reservoirs Rambakenwewa and Mahaoya) of eastern province Sri Lanka, this values are lower than present study.Also according to the Jinadasa, Subasinghe [55], the $\mathrm{Hg}$ concentration of Oreochromis spp (0.011 ppm) that collected from reservoirs of Anuradhapura and Polonnaruwa districts Sri Lanka, was not exceed the value of the present study, however it was exceed the value of the Oreochromis spp $(0.26 \mathrm{ppm})$ that was recorded by Jinadasa and Edirisinghe [56].

Arsenic was only detected from three regurgitated material samples that collected from Belummahara $(0.04 \mathrm{ppm}$ in Crab sample and $0.19 \mathrm{ppm}$ in Grasshopper sample) and Kadugannawa (0.04 ppm in Grasshopper sample). According 
to the results As concentration was highly depended on faunal species(Figure 3). These values are much lower than As concentration of preys in Cattle egrets $(0.55 \mathrm{ppm})$, that observed by Boncompagni, Muhammad [26] in Taunsa Pakistan. The Zhang, Ruan [28] found that higher mean As concentration in prey of little egrets $(2.03 \mathrm{ppm})$ than present value. There are many studies of As concentration of freshwater fish fauna in Sri Lanka. Jinadasa, Ariyarathne [54] were observed that Aresenic in inland fish species Orinoco Sailfin Catfish (Pterygoplichthy smultiradiatus) $\quad(<0.004$ ppm) from two reservoirs Rambakenwewa and Mahaoya) of eastern province Sri Lanka, this values are lower than present study. According to the Jinadasa, Subasinghe [55], As was not detected of Oreochromis sppthat collected from reservoirs of Anuradhapura and Polonnaruwa districts Sri Lanka, however Allinson, Nishikawa [57] and Allinson, Salzman [58] observed that As concentration of Oreochromis mossambicus $(0.26 \mathrm{ppm})$ and Oreochromis niloticus $(<0.90$ ppm)respectively from reservoirs of south Sri Lanka.

When consider the regurgitated samples that were collected from fledglings of Kandy lake, Amblypharyngodon melattinus, Puntius dorsalis, Puntius filamentosus, Esomus thermoicos were common.

According to the multiple comparisons, highest $\mathrm{Cd}$ concentration of regurgitated materials was detected in the Kandy Lake ( 0.003 to $0.005 \mathrm{mg} / \mathrm{kg}$ ) in present study (Figure 3 ), that was lower than observed $\mathrm{Cd}$ concentration in prey items of Little egret $(1.09 \mu \mathrm{g} / \mathrm{g})$ and Cattle egret $(1.01$ $\mu \mathrm{g} / \mathrm{g})$ in Pakistan by Shahbaz, Hashmi [59]. The Boncompagni, Muhammad [26] also detected high $\mathrm{Cd}$ concentration of prey items in Intermediate egret $(0.09 \mathrm{ppm})$, Little egret $(0.10 \mathrm{ppm})$ and Cattle egret $(0.06 \mathrm{ppm})$ in Pakistan than present study. Also the Zhang, Ruan [28] found that higher mean $\mathrm{Cd}$ concentration in prey of little egrets in Tai lake $(0.07 \mathrm{ppm})$ and Poyang lake $(0.18 \mathrm{ppm})$ of China. There are some records are available for $\mathrm{Cd}$ concentration of freshwater fish fauna in Sri Lanka. According to the Indrajith, Pathiratne [53] the Cd concentration of two fish species, Etroplus suratensis(0.011 - $0.027 \mathrm{ppm})$ and Ambassis commersoni (0.001- $0.034 \mathrm{ppm}$ ) were detected from 12 sites ofNegombo estuary. The concentrations are exceeding the values of the present study.Jinadasa, Ariyarathne [54] was observed that Cd in inland fish species Orinoco Sailfin Catfish (Pterygoplichthy smultiradiatus) (Male: - 0.005 and Female: - 0.004 ppm) from two reservoirs Rambakenwewa and Mahaoya) of eastern province Sri Lanka, this values are much closer to present study.Also according to the Jinadasa, Subasinghe [55], the $\mathrm{Cd}$ concentration of Oreochromis spp (0.001 ppm) that collected from reservoirs of Anuradhapura and Polonnaruwa districts Sri Lanka, was exceed the value of the present study. Also the value of present study was lower than the value of the Oreochromis spp $(0.034 \mathrm{ppm})$ that was recorded by Jinadasa and Edirisinghe 2012. [59].

In present study runoff water from highways were accumulated to foraging areas of all heronries. With this runoff, automobile effluents are continuously adding to the water bodies which occurred within the vicinity of the breeding colonies. However $\mathrm{pb}$ was also not detected in regurgitated materials in any sites.

\subsection{Hg, As, Cd and Pb in Water Samples}

One-way ANOVA was applied to investigate the presence of variation between water samples which collected from foraging grounds of Little Egrets from five sites for $\mathrm{Hg}$, As, $\mathrm{Cd}$ and $\mathrm{Pb}$ in $2014(\mathrm{Hg} ; \mathrm{F}=38.41, P<0.05$, As; $\mathrm{F}=42.61$, $P<0.05, \quad \mathrm{Cd} ; \mathrm{F}=4.87, P<0.05, \quad \mathrm{~Pb} ; \mathrm{F}=2.32, \quad P<0.05) . \quad$ A significant variation ofHg, $\mathrm{As}, \mathrm{Cd}$ and $\mathrm{Pb}(p<0.05)$ was observed between sites. The Tukey's test was used to identify significant differences between mean values of five sites for the metal which was found to be significant in one-way ANOVA test. Tukey's test showed that, Cd concentration of water high in Kadugannawa heronry. Although $\mathrm{Hg}$ concentrations in water were high in both Kandy Lake and Kadugannawa than other sites, there was no significant variation between these two sites. However, multiple comparison tests showed that the $\mathrm{Hg}$ concentration in water were high in Kadugannawa.

Mean $\mathrm{Hg}$ concentration of water in foraging areas of five sites range from ND to1.6 ppb (Figure 4) and it was exceeding standard level for drinking water (1 ppb) by WHO [60]. It was lower than the $\mathrm{Hg}$ concentration of drinking water (8-31 ppb),that reported by Jayasumana, Paranagama [61] in Padawiya and Mahawilachchiya drinking water sources of CKDU patient area in Sri Lanka. Indrajith, Pathiratne [53],reported that mean $\mathrm{Hg}$ concentration water below the detection limits $(10 \mathrm{ppb})$ from 12 sites of Negombo estuary. There was no much of publish studies of $\mathrm{Hg}$ in water in Sri Lanka. Although there was no any significant correlation between $\mathrm{Hg}$ concentration of water in foraging areas, regurgitated materials and feathers of fledglings were observed $(>0.05)$, some type of accumulation of was observed. However mean $\mathrm{Hg}$ concentration of the present study was increased from concentration of water to regurgitated materials and towards feathers of Little Egrets.

When consider As concentration of water samples that collected from foraging areas of the heronries, range from 0.1 to $3.82 \mathrm{ppb}$ (Figure 4). It was not exceeded the standards of drinking water $(0.01 \mathrm{mg} / \mathrm{l})$ and irrigation water $(0.1 \mathrm{mg} / \mathrm{l})$ by WHO [60]. According to Jayasumana, Paranagama [61], Arsenic concentration of drinking water (73-208 ppb) sources of CKDU patient area in Padawiya and Mahawilachchiya of Sri Lanka exceed thousand times than present study. In a study conducted by Kawakami and Serikawa [62]Arsenic levels were measured in well water samples collected from Anuradhapura, Nuwara Eliya, Puttalam, Mannar and Jaffna, and the mean concentrations were $0.3,0.1,3.7,7.4$ and $1.9 \mu \mathrm{g} / \mathrm{L}$, respectively. The results show some similarity for present data except As concentration of Jaffna area of above study. Although there was no significant correlation of As concentration of water in foraging areas, regurgitated materials and feathers of fledglings, the results show that the As were also accumulated in food chain from water to feathers of Little 
Egrets through their prey items.

Also in the present study mean Cd concentrations in water was range from 0.03 to 0.11 (ppb)(Figure 4). That was not exceeding threshold limit for aquatic fauna and maximum contamination level (3 ppb) of WHO [60]. Also it was not exceed the standards of drinking water for $\mathrm{Cd}(0.001 \mathrm{ppm})$ and irrigation water $(0.01 \mathrm{ppm})$ WHO [60]. Mean concentration of $\mathrm{Cd}$ was low compared to $\mathrm{Cd}(2.7 \mathrm{ppb})$ that detected from Kelani River in Colombo [63].Senaratne and Pathiratne [64] reported mean Cd concentration in water was vary from 6.1 to 312.6 (ppb) of Bolgoda Lake Sri Lanka.
Indrajith, Pathiratne [53] reported that mean Cd concentration water vary ND to $2.1(\mathrm{ppb})$ from 12 sites of Negombo estuary. According to the review of Ileperuma [2], the $\mathrm{Cd}$ concentration of water in Kandy Lake was varying from 10 to 90 (ppb). It was thousand times greater than $\mathrm{Cd}$ in water of Kandy Lake in the present study that range from 0.05 to $0.06 \mu \mathrm{g} / \mathrm{L}$. Also according to the Bandara, Senevirathna [65], The Cd concentration of water in five reservoirs of North Central Province in Sri Lanka (range from 30-60 ppb) was thousand times greater than present study.

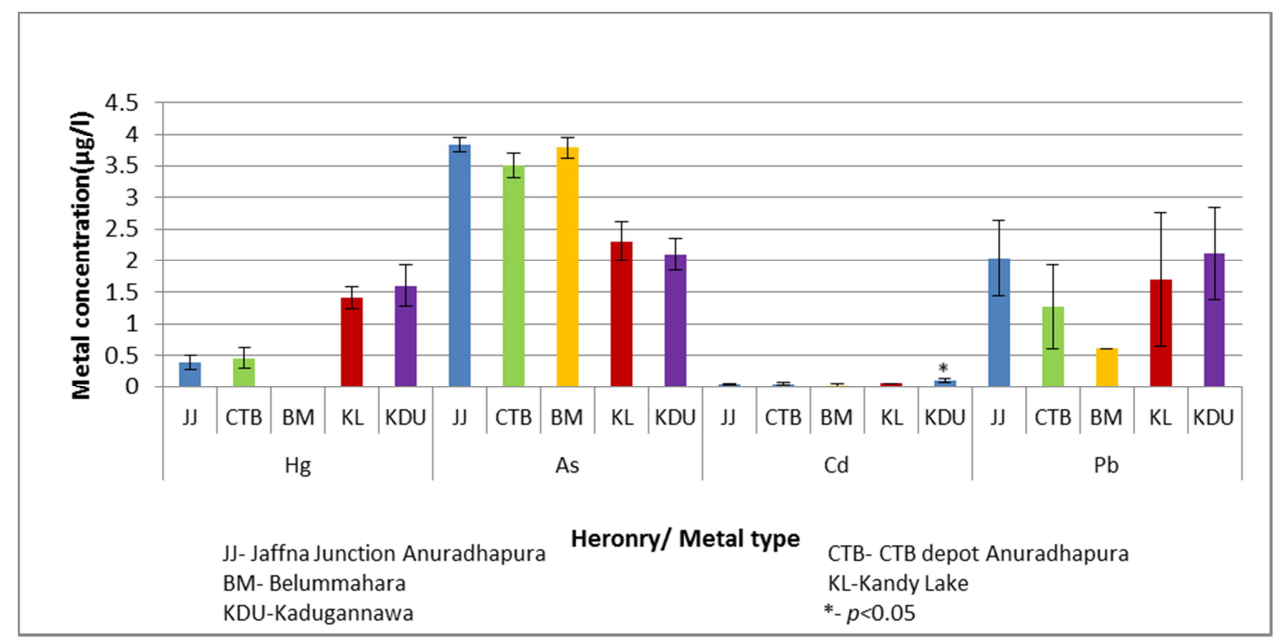

Figure 4. Mean metal concentration in water from foraging areas of Egretta garzetta( $\mu \mathrm{g} / \mathrm{l})$.

In the present study mean $\mathrm{Pb}$ concentrations were detected in water that collected from foraging areas of breeding colonies, but in small concentrations, range from 0.61 to 2.11 $\mu \mathrm{g} / \mathrm{L}($ Figure 4$)$, that was not exceeded standards levels of drinking water $(0.01 \mathrm{mg} / \mathrm{l})$ and irrigation water $(5 \mathrm{mg} / \mathrm{l})[60]$.

Mean concentration of $\mathrm{Pb}$ was low compared to $\mathrm{Pb}$ (7.4 $\mu \mathrm{g} / \mathrm{L})$ that detected from Kelani River in Colombo [63].Senaratne and Pathiratne [64], reported that mean $\mathrm{Pb}$ concentration in water was vary from 23.2 to $36.3 \mu \mathrm{g} / \mathrm{L}$ of Bolgoda Lake Sri Lanka. Also Indrajith, Pathiratne [53], reported that mean $\mathrm{Pb}$ concentration water range from ND to $5.7 \mu \mathrm{g} / \mathrm{L}$ from 12 sites of Negombo estuary Sri Lanka. According to the review of Ileperuma [2], the pb concentration of water in Kandy Lake was vary from 100 to $390 \mu \mathrm{g} / \mathrm{L}$. It was hundred times greater than $\mathrm{Pb}$ in water of Kandy Lake that range from 0.65 to $2.77 \mu \mathrm{g} / \mathrm{L}$ in the present study.

\subsection{Accumulation of $\mathrm{Hg}, \mathrm{As}, \mathrm{Cd}$ and $\mathrm{Pb}$ in Food Chains}

Although theoretically all four metals should be accumulated through water to regurgitated materials and to feathers, no accumulation of $\mathrm{Pb}$ could be observed through water to feathers. Only the accumulation of $\mathrm{Hg}$, As and $\mathrm{Cd}$ was observed in this particular food chain except in certain heronries. However, this observation lacks evidence to claim that $\mathrm{Pb}$ is not present in the environment (Figure 5).
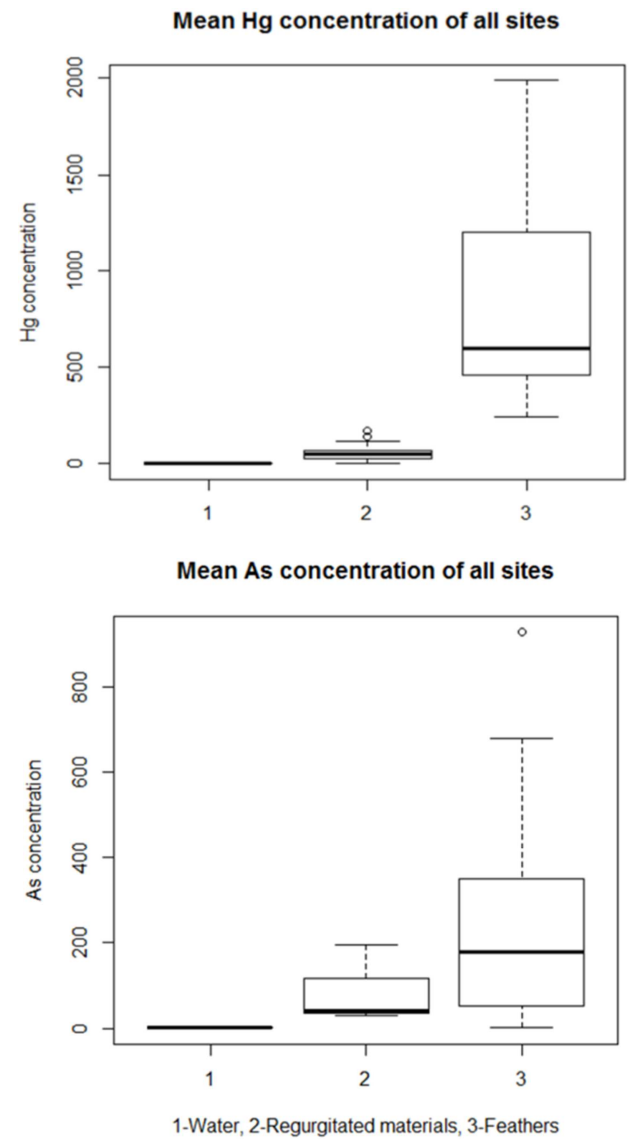


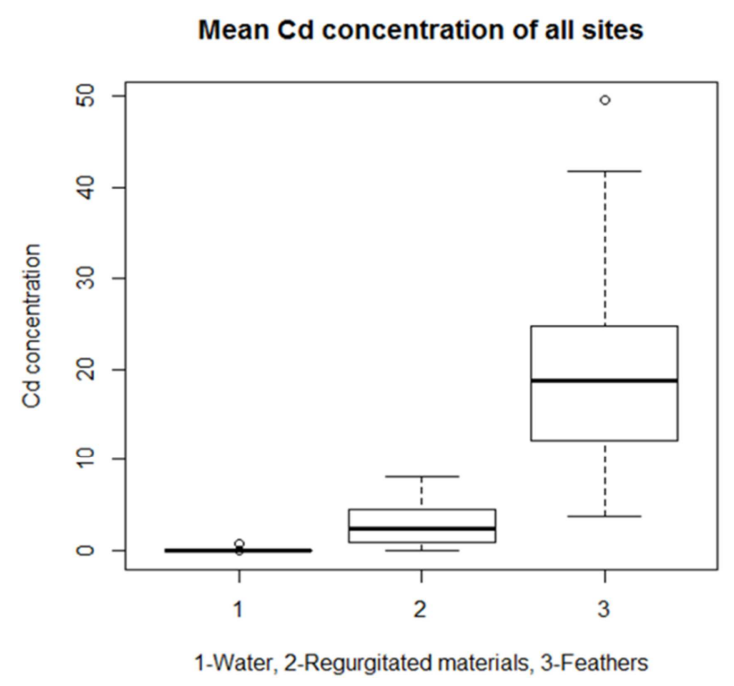

Figure 5. Box plot of heavy metal accumulation through food chain (water, regurgitated and feather samples) in overall study.

When using adult bird feathers as a bio monitoring tool, it is difficult to define exact foraging area and it is difficult to assume the real source of heavy metal, because they move within a large foraging area to get their food. To minimize this problem Burger and Gochfeld [66] proposed to use sedentary species or young birds that have not yet fled and still under parental care and fed by their parents. When compared to adult feathers, using of fledgling feathers narrows down the spacial and temporal sampling space.

There were no significant differences between wash and non-wash feathers in present study. According to the Dmowski [67], none of the routinely applying feathers cleaning methods such as washing them in bidets water, acetone, hexane, ether, non-ionic detergents such as Triton X100 or exposition to ultrasounds, do not remove all external pollutants. Also Weyers, Glück [68] demonstrated by the use of SEM micrographs of cleaned and not cleaned Black bird feathers, that even very intensive washing does not remove all dust particles from within the entangled structures of microfilaments created by barbs and barbules. By using of fledgling feathers that 8 to 10 weeks old, will be minimized the above problem.

By analyzing heavy metals in water within the catchment area of the heronries, it gives clear idea about the metal concentrations of the initial stage in food chain. By digesting of the water samples, the heavy metals in plankton also detected. So the results give total heavy metal concentration in water sample with heavy metals in primary producers.

Although there are some differences of land use patterns in these five sites, all sites are urbanized or semi urbanized. According to the preliminary survey the Little egrets were nesting in places near to the human settlements within urbanized and semi urbanized areas. Although there are nesting heronries in tank ecosystems, little egrets were rare. The tank ecosystems are also connected with paddy fields and other irrigation lands by cascade system that constructed in ancient period in Sri Lanka. Because of that no any reference site was selected for this study.
These findings proved that by using of feathers as a bio monitoring tool for small country like Sri Lanka

\section{Conclusion}

For this study we selected to measure the most relevant heavy metals based on past studies in Sri Lanka. The purpose of this study was to find the suitability of bird feathers as a biomonitoring tool for ecosystems in Sri Lanka. A list of criteria that can be used to select a suitable biomonitor was established after analyzing different egret species and their various tissues for $\mathrm{Hg}, \mathrm{As}, \mathrm{Pb}$ and $\mathrm{Cd}$ concentration levels. According to the findings, Little Egret fledgling feathers were the most suitable biomonitor that can assess the variations in spatial and temporal patterns of metal concentrations in aquatic ecosystems in Sri Lanka. In addition, bioaccumulation patterns of the above heavy metals were determined in order to determine whether they could have detrimental effects on humans and ecosystem health. Although the metal concentration levels in water were below threshold levels, biomonitoring allow us to monitor the metal concentrations in ecosystems. Furthermore, we established a freely accessible database of heavy metal concentrations in Sri Lanka which is available to both local and global researchers. $\mathrm{Hg}$ was detected in relatively high levels and significant variations were reported from locations tested. According to the results of the present study, feathers of little egret fledglings can be used as a bio monitoring tool to measure the bio accumulation of $\mathrm{Hg}$, As and $\mathrm{Cd}$. Lead may not be excreted by the bird at detectable levels into the feather or the sites have no detectable levels of $\mathrm{Pb}$. Thus this tool needs to be used cautiously to avoid interpretation errors. All in all it has promise to be a successful bio monitoring tool.

\section{Acknowledgements}

We are most grateful for financial support through the HETC grant (HETC/CMB/QIG/W3). Also thanks to Department of Wildlife \& Conservation for giving permission to carry out this study and our sincere thanks to the head, department of Zoology \& Environmental Sciences, Faculty of Science, University of Colombo for giving strong support and advice during the survey. Our special thanks go to Nilantha Kumudu Kumara and Ranjan Dissanayake, Faculty of Applied Sciences Rajarata University, Mihintale.

\section{References}

[1] Gunawardene NR, Daniels DA, Gunatilleke I, Gunatilleke C, Karunakaran P, Nayak GK, et al. A brief overview of the Western Ghats-Sri Lanka biodiversity hotspot. Current science. 2007; 93 (11): 1567-72.

[2] Ileperuma O. Environmental pollution in Sri Lanka: a review. Journal of the National Science Foundation of Sri Lanka. 2000; 28 (4): 301-25. 
[3] Batagoda B, Sugathapala A, Yalegama M, B. J. Urban Air Quality Management in Sri Lanka Colombo. Air Resource Management Center (AirMAC) Ministry of Environment and Natural Resources; Sri Lanka. 2004; p. iii.

[4] National environment act. 1994

[5] Furness RW, Greenwood JJ. Birds as monitors of environmental change: Springer Science \& Business Media; 1993.

[6] Burger J. Metals in avian feathers: bioindicators of environmental pollution. Rev Environ Toxicol. 1993; 5: 203-311.

[7] Kushlan JA, Hancock JA. Herons: OUP Oxford; 2005.

[8] Mañosa S, Mateo R, Guitart R. A review of the effects of agricultural and industrial contamination on the Ebro delta biota and wildlife. Environmental Monitoring and Assessment. 2001; 71 (2): 187-205.

[9] Furness RW, Camphuysen KC. Seabirds as monitors of the marine environment. ICES Journal of Marine Science: Journal du Conseil. 1997; 54 (4): 726-37.

[10] De Luca-Abbott SB, Wong BS, Peakall DB, Lam PK, Young L, Lam $\mathrm{MH}$, et al. Review of effects of water pollution on the breeding success of waterbirds, with particular reference to ardeids in Hong Kong. Ecotoxicology. 2001; 10 (6): 327-49.

[11] Connell D, Fung C, Minh T, Tanabe S, Lam P, Wong B, et al Risk to breeding success of fish-eating Ardeids due to persistent organic contaminants in Hong Kong: evidence from organochlorine compounds in eggs. Water Research. 2003; 37 (2): 459-67.

[12] Champoux L, Rodrigue J, Trudeau S, Boily MH, Spear PA, Hontela A. Contamination and biomarkers in the great blue heron, an indicator of the state of the St. Lawrence River. Ecotoxicology. 2006; 15 (1): 83-96

[13] Matsinos YG, Wolff W. An individual-oriented model for ecological risk assessment of wading birds. Ecological modelling. 2003; 170 (2): 471-8.

[14] Burger J, Eichhorst B. Heavy metals and selenium in grebe eggs from Agassiz National Wildlife Refuge in northern Minnesota. Environmental monitoring and assessment. 2005; 107 (1-3): 285-95.

[15] Scheuhammer AM, Meyer MW, Sandheinrich MB, Murray MW. Effects of environmental methylmercury on the health of wild birds, mammals, and fish. AMBIO: A Journal of the Human Environment. 2007; 36 (1): 12-9.

[16] Kotagama SW, Ratnavira G. An illustrated guide to the birds of Sri Lanka: Field Ornithology Group of Sri Lanka; 2010.

[17] Custer TW, Pendleton G, Ohlendorf HM. Within-and amongclutch variation of organochlorine residues in eggs of blackcrowned night-herons. Environmental Monitoring and Assessment. 1990; 15 (1): 83-9.

[18] Harrison J, Worfolk T. A field guide to the birds of Sri Lanka: Oxford University Press; 2011.

[19] Henry GM. A guide to the birds of Sri Lanka: Oxford University Press, USA; 1998.

[20] Edmond J, Stallard R, Craig H, Craig V, Weiss R, Coulter G. Nutrient chemistry of the water column of Lake Tanganyika. Limnology and Oceanography. 1993; 38 (4): 725-38.
[21] Tuzen M, Soylak M. Evaluation of metal levels of drinking waters from the Tokat-Black sea region of Turkey. Polish Journal of Environmental Studies. 2006; 15 (6): 915.

[22] Longcore JR, Locke L, Bagley GE, Andrews R. Significance of lead residues in mallard tissues. US Fish and Wildlife Service, 1974

[23] Johnson M, Pluck H, Hutton M, Moore G. Accumulation and renal effects of lead in urban populations of feral pigeons, Columba livia. Archives of environmental contamination and toxicology. 1982;11 (6): 761-7.

[24] Custer TW, Franson JC, Pattee OH. Tissue lead distribution and hematologic effects in American kestrels (Falco sparverius L.) fed biologically incorporated lead. Journal of Wildlife Diseases. 1984; 20 (1): 39-43.

[25] Garcia-Fernandez AJ, Sanchez-Garcia JA, Jimenez-Montalban P, Luna A. Lead and cadmium in wild birds in southeastern Spain. Environmental Toxicology and Chemistry: An International Journal. 1995;14(12):2049-58.

[26] Boncompagni E, Muhammad A, Jabeen R, Orvini E, Gandini C, Sanpera C, et al. Egrets as monitors of trace-metal contamination in wetlands of Pakistan. Archives of Environmental Contamination and Toxicology. 2003; 45 (3): 399-406.

[27] Goutner V, Furness R. Mercury in feathers of little egret Egretta garzetta and night heron Nycticorax nycticorax chicks and in their prey in the Axios Delta, Greece. Archives of environmental contamination and toxicology. 1997; 32 (2): 211-6.

[28] Zhang Y, Ruan L, Fasola M, Boncompagni E, Dong Y, Dai N, et al. Little Egrets (Egretta garzetta) and trace-metal contamination in wetlands of China. Environmental monitoring and assessment. 2006; 118 (1-3): 355-68.

[29] Frederick PC, Spalding MG, Dusek R. Wading birds as bioindicators of mercury contamination in Florida, USA: annual and geographic variation. Environmental Toxicology and Chemistry. 2002; 21 (1): 163-7.

[30] Tsipoura N, Burger J, Newhouse M, Jeitner C, Gochfeld M, Mizrahi D. Lead, mercury, cadmium, chromium, and arsenic levels in eggs, feathers, and tissues of Canada geese of the New Jersey Meadowlands. Environmental research. 2011; 111 (6): $775-84$

[31] Sepúlveda MS, Frederick PC, Spalding MG, Williams GE. Mercury contamination in free-ranging great egret nestlings (Ardea albus) from Southern Florida, USA. Environmental Toxicology and Chemistry. 1999; 18 (5): 985-92.

[32] Padula V, Burger J, Newman S, Elbin S, Jeitner C. Metals in feathers of black-crowned night-heron (Nycticorax nycticorax) chicks from the New York Harbor Estuary. Archives of environmental contamination and toxicology. 2010; 59 (1): 157-65

[33] Thompson D, Furness R, Heinz G. Environmental contaminants in wildlife: interpreting tissue concentrations. Beyer, Heinz, Redmon-Norwood (Eds) New York. 1996.

[34] Gochfeld M. Spatial patterns in a bioindicator: heavy metal and selenium concentration in eggs of Herring gulls (Larus argentatus) in the New York Bight. Archives of environmental contamination and toxicology. 1997; 33 (1): 63-70. 
[35] Burger J, Gochfeld M. Spatial and temporal patterns in metal levels in eggs of common terns (Sterna hirundo) in New Jersey. Science of the Total Environment. 2003; 311 (1): 91100.

[36] Wolfe MF, Schwarzbach S, Sulaiman RA. Effects of mercury on wildlife: a comprehensive review. Environmental toxicology and chemistry. 1998; 17 (2): 146-60.

[37] Carty A, Malone S. The chemistry of mercury in biological systems. The biogeochemistry of mercury in the environment. 1979; 3: 433-79.

[38] Eisler R, editor Mercury hazards to fish, wildlife, and invertebrates: a synoptic review. US Fish and Wildlife Service Biological Report 85: 90. US Fish and Wildlife Service, Biol Rep; 1987: Citeseer.

[39] Evers DC, Savoy LJ, DeSorbo CR, Yates DE, Hanson W, Taylor KM, et al. Adverse effects from environmental mercury loads on breeding common loons. Ecotoxicology. 2008; 17 (2): 69-81.

[40] Staszewski T, Malawska M, Studnik-Wójcikowska B, Galera $\mathrm{H}$, Wiłkomirski B. Soil and plants contamination with selected heavy metals in the area of a railway junction/Zanieczyszczenie gleby i roślin wybranymi metalami ciężkimi na terenie węzła kolejowego. Archives of Environmental Protection. 2015; 41 (1): 35-42.

[41] Fayiga AO, Ma LQ, Zhou Q. Effects of plant arsenic uptake and heavy metals on arsenic distribution in an arseniccontaminated soil. Environmental Pollution. 2007; 147 (3): 737-42.

[42] Nighat S, Iqbal S, Nadeem MS, Mahmood T, Shah SI. Estimation of heavy metal residues from the feathers of Falconidae, Accipitridae, and Strigidae in Punjab, Pakistan. Turkish Journal of Zoology. 2013; 37 (4): 488-500.

[43] Malik RN, Zeb N. Assessment of environmental contamination using feathers of Bubulcus ibis L., as a biomonitor of heavy metal pollution, Pakistan. Ecotoxicology. 2009; 18 (5): 522-36.

[44] Fasola M, Movalli P, Gandini C. Heavy metal, organochlorine pesticide, and PCB residues in eggs and feathers of herons breeding in northern Italy. Archives of Environmental Contamination and Toxicology. 1998; 34 (1): 87-93.

[45] Burger J, Gochfeld M. Heavy metal and selenium levels in feathers of young egrets and herons from Hong Kong and Szechuan, China. Archives of environmental contamination and toxicology. 1993; 25 (3): 322-7.

[46] Burger J, Gochfeld M. Metal levels in feathers of 12 species of seabirds from Midway Atoll in the northern Pacific Ocean. Science of the Total Environment. 2000; 257 (1): 37-52.

[47] Burger J. Heavy metal and selenium levels in feathers of Franklin's gulls in interior North America. The Auk. 1996: 399-407.

[48] Burger J, Carlucci SA, Jeitner CW, Niles L. Habitat choice, disturbance, and management of foraging shorebirds and gulls at a migratory stopover. Journal of Coastal Research. 2007: 1159-66.

[49] Deng H, Zhang Z, Chang C, Wang Y. Trace metal concentration in great tit (Parus major) and greenfinch (Carduelis sinica) at the Western Mountains of Beijing, China.
Environmental Pollution. 2007; 148 (2): 620-6.

[50] Kim J, Koo T-H. Heavy metal distribution in chicks of two heron species from Korea. Archives of environmental contamination and toxicology. 2008; 54 (4): 740-7.

[51] Movalli P. Heavy metal and other residues in feathers of laggar falcon Falco biarmicus jugger from six districts of Pakistan. Environmental Pollution. 2000; 109 (2): 267-75.

[52] Metcheva R, Yurukova L, Teodorova S, Nikolova E. The penguin feathers as bioindicator of Antarctica environmental state. Science of the total environment. 2006; 362 (1): 259-65.

[53] Indrajith H, Pathiratne K, Pathiratne A. Heavy metal levels in two food fish speceis from Negombo estuary, Sri Lanka: Relationships with the body size. Sri Lanka J Aquat Sci. 2008; 13: 63-81.

[54] Jinadasa B, Ariyarathne D, Ahmad S. Trace metal contaminants in tissues of the Orinoco Sailfin Catfish Pterygoplichthy smultiradiatus, (Hancock, 1828); Sri Lanka. Nature and Science. 2014; 12 (6): 1-4.

[55] Jinadasa B, Subasinghe M, Thayalan K, Wickramasinghe I, de Silva M. Trace Metal Contents in Muscle Tissues of Inland Fish Species in the North central Province of Sri Lanka. Ceylon Journal of Science (Bio Sci). 2013; 42 (2): 79-86.

[56] Jinadasa B, Edirisinghe E, 1-14. Assessment of Heavy Metals (Cadmium, Lead and Total Mercury) in Tilapia sp. in Sri Lanka. National Aquatic Resources Research \& Development Agency of Sri Lanka. 2012; 43: 1-14.

[57] Allinson G, Nishikawa M, De Silva S, Laurenson L, De Silva $\mathrm{K}$. Observations on metal concentrations in tilapia (Oreochromis mossambicus) in reservoirs of south Sri Lanka. Ecotoxicology and environmental safety. 2002; 51 (3): 197202.

[58] Allinson G, Salzman S, Turoczy N, Nishikawa M, Amarasinghe U, Nirbadha K, et al. Trace metal concentrations in Nile tilapia (Oreochromis niloticus) in three catchments, Sri Lanka. Bulletin of environmental contamination and toxicology. 2009; 82 (3): 389-94.

[59] Shahbaz M, Hashmi MZ, Malik RN, Yasmin A. Relationship between heavy metals concentrations in egret species, their environment and food chain differences from two Headworks of Pakistan. Chemosphere. 2013; 93 (2): 274-82.

[60] WHO. Guidelines for Drinking-water Quality. WHO chronicle. $2011 ; 38$ : 104-8.

[61] Jayasumana C, Paranagama P, Amarasingehe M, editors. Chronic Kidney Disease of Unknown Ethiology (CKDu) and Arsenic in Groundwater in Sri Lanka. Workshop on Challenges in Groundwater Management in Sri Lanka; 2011.

[62] Kawakami W, Serikawa M. Contamination of Arsenic in Well water and rice in Sri Lanka. 2012.

[63] Dissanayake C, Weerasooriya S, Senaratne A, Rupasinghe M. The heavy metal pollution of the Kelani River in Sri Lanka. Aqua. 1985; 2: 79-88.

[64] Senaratne, Pathiratne. Accumulation of heavy metals in a food fish, Mystus gulio inhabiting Bolgoda Lake, Sri Lanka. Sri Lanka J Aquat Sci. 2007; 12: 61-75. 
[65] Bandara JMRS, Senevirathna DMAN, Dasanayake DMRSB, Herath V, Bandara JMRP, Abeysekara T, et al. Chronic renal failure among farm families in cascade irrigation systems in Sri Lanka associated with elevated dietary cadmium levels in rice and freshwater fish (Tilapia). Environmental Geochemistry and Health. 2008; 30 (5): 465-78.

[66] Burger J, Gochfeld M. Metal levels in eggs of common terns (Sterna hirundo) in New Jersey: temporal trends from 1971 to 2002. Environmental Research. 2004; 94 (3): 336-43.
[67] Dmowski K. Birds as bioindicators of heavy metal pollution: review and examples concerning European species. Acta Ornitologica. 1999; 34: 1-25.

[68] Weyers B, Glück E, Stoeppler M. Investigation of the significance of heavy metal contents of blackbird feathers. Science of the total environment. 1988; 77 (1): 61-7. 